\title{
Quotients Homophones des Groupes Libres Homophonic Quotients of Free Groups
}

\author{
Jean-François Mestre, René Schoof, Lawrence Washington, Don Zagier
}

Ah, la recherche! Du temps perdu.

Soit $G$ le quotient du groupe libre à 26 générateurs $a, b, c, \ldots, z$ par les relations $A=B$, pour tout couple de mots $(A, B)$ pouvant avoir la même prononciation en anglais. (Un groupe défini d'une manière analogue a été considéré dans [Landsburg 1986].) Notre but est de déterminer la structure du groupe $G$.

Théorème. G est trivial.

Démonstration. (Nous nous servirons sans le mentionner des faits contenus dans (Stein 1973].) La relation homophone bye $=b y$ implique que $e$ est trivial dans $G$ (en symboles: $e=e$ ), après quoi les identités

$$
\begin{gathered}
\text { lead }=l e d, \quad \text { maid }=\text { made }, \quad \text { sow }=\text { sew } \\
\text { buy }=b y, \quad \text { sow }=\text { so }, \quad \text { lye }=l i e
\end{gathered}
$$

nous donnent la trivialité des autres voyelles et demivoyelles $a, i, o, u, w$ et $y$. La trivialité des générateurs $h, k, n, p$ et $b$ est une conséquence des formules

$$
\begin{gathered}
\text { hour }=\text { our }, \quad \text { knight }=\text { night }, \quad \text { damn }=d a m, \\
\text { psalter }=\text { salter }, \quad \text { plumb }=\text { plum, }
\end{gathered}
$$

tandis que celle des générateurs $s, t, l, r$ et $m$ se déduit des égalités

$$
\begin{gathered}
\text { bass }=\text { base }, \quad \text { butt }=\text { but }, \quad \text { tolled }=\text { told }, \\
\text { barred }=\text { bard }, \quad \text { dammed }=\text { damned }
\end{gathered}
$$

(méthode des idempotents). Pour les générateurs
Let $G$ be the quotient of the free group on 26 letters $a, b, c, \ldots, z$ by the relations $A=B$ whenever $A$ and $B$ are words having the same pronunciation in French. (A similarly defined group was considered in [Landsburg 1986].) The object of this paper is to determine the structure of $G$.

Theorem. $G$ is trivial.

Proof. (We use without special mention facts that can be found in [Robert 1973].) The relation

$$
\text { soie }=s o i
$$

shows, on canceling soi (reflexive property!), that $e$ is trivial in $G$ (in symbols, $e=e$ ). A similar argument applied to the final letters of soit, sois and aux shows that $t, s$ and $x$ are also trivial. The triviality of $r$ follows from the well-known fact

$$
\text { serre }=\text { sert }
$$

[Lam 1978], and that of $c, l, d, h$ and $n$ from

$$
\begin{gathered}
c e=s e, \quad \text { balle }=\text { bal }, \quad \text { laid }=\text { lait }, \\
\text { haut }=\text { au, } \quad \text { parlent }=\text { parle }
\end{gathered}
$$

after which the relations

$$
\begin{aligned}
\text { allez } & =\text { aller }, \quad \text { sept }=\text { cet } \\
\text { champs } & =\text { chant }, \quad \text { fard }=\text { phare }
\end{aligned}
$$

allow one to eliminate $z, p, m$ and $f$. (One could give a proof with a more topological flavor of the triviality of $f$ using cerf $=$ serre.) The triviality 
$d$ et $g$ de $G$ on se sert des équations

$$
\text { chased }=\text { chaste }, \quad \text { sign }=\text { sine },
$$

après quoi les équations

$$
\begin{gathered}
\text { daze }=\text { days }, \quad \text { cite }=\text { sight }, \quad \text { jeans }=\text { genes }, \\
\text { queue }=\text { cue }, \quad \text { tax }=\text { tacks }
\end{gathered}
$$

nous permettent d'éliminer également $z, c, j, q$ et $x$. En se servant des relations du type $r u f f=$ rough on voit facilement que l'élément $f$ de $G$ est de torsion $\left(f^{2}=e\right)$, mais en fait il est trivial à cause de l'identité

$$
\text { phase }=\text { faze }
$$

(phrase $=$ frays servirait également). Enfin, on peut éliminer le générateur $v$ de $G$ à l'aide de l'équation

$$
\text { chivvy }=\text { chivy }
$$

(ou leitmotiv = leitmotif $).$

\section{GÉNÉRALISATIONS}

On peut généraliser le théorème en considérant le group $G_{0}$ défini de la même manière que $G$, mais avec un espace comme 27 ième générateur. Alors la relation

$$
\text { be } \mathrm{calm}=\text { becalm }
$$

montre la trivialité du nouveau générateur, et la relation

$$
\text { avowers }=\text { of ours }
$$

donne une preuve plus satisfaisante qu'avant de celle du générateur $v$.

Il semble en plus que l'on puisse démontrer un théorème analogue dans le cas où "anglais" est remplacé par "français" dans la définition de $G$.

\section{APPLICATIONS}

On a lieu de croire que le théorème ci-dessus aura des applications dans l'investigation de la conjecture $p=n p$. of the vowels $a, i, y$ follows successively from the identities

$$
a n=e n, \quad \text { mais }=\text { mets }, \quad \text { bayer }=\text { bailler },
$$

after which that of $g, j, b$ follows from

$$
\text { sang }=\text { cent }, \quad \text { jet }=\text { geai }, \quad \text { abbesse }=\text { abaisse } .
$$

The letters $k, q, u, o$ are more difficult:

$$
k h a n=\text { quand }, \quad \text { lacque }=\text { lac }
$$

imply that $k=q u$ and that $q u$ is trivial. Next, $\operatorname{coq}=$ coke yields the triviality of $q$, hence of $u$. Finally, pot $=$ peau implies that $o$ is trivial. The triviality of the remaining letters $w$ and $v$ now follows from the relations

$$
\text { watt }=\text { ouate }, \quad \text { vaguons }=\text { wagon } .
$$

This completes the proof of the theorem.

\section{GENERALIZATIONS}

The theorem generalizes to the enlarged group $\hat{G}^{\prime}$ obtained by adjoining to the set of generators all accented letters and $\propto$, as one sees using

$$
\begin{aligned}
& \text { là }=l a(\text { or simply } \grave{a}=a), \quad \text { guère }=\text { guerre, } \\
& \text { allée }=\text { aller }, \quad \hat{o t e}=\text { haute }, \quad \text { appât }=\text { appas } \text {, } \\
& m \hat{u} r=m u r, \quad \hat{\imath} l e=i l, \quad \text { fête }=\text { faîte }, \\
& \text { œufs }=\text { eux }, \quad c ̧ a=s a .
\end{aligned}
$$

One can also allow the apostrophe and the trait d'union using: m'aime $=$ même, voix-ci $=$ voici.

Another generalization which naturally suggests itself is that to other languages. We can prove that the theorem remains true with "French" replaced by "English" in the definition of $G$. The corresponding theorem for "German" has been proved very recently by Herbert Gangl, following previous pioneering work by Norbert Schappacher. On the other hand, it appears that the analogously defined group for Japanese (written in katakana) is free on 46 generators. 


\section{REMERCIEMENTS}

Les auteurs tiennent a remercier Jean-Pierre Serre pour le grand interêt qu'il a porté à notre travail.

\section{BIBLIOGRAPHIE}

[Landsburg 1986] S. Landsburg, "The Jimmy's book", Amer. Math. Monthly 93 (1986), 636-638.

[Stein 1973] J. Stein (editor), The Random House Dictionary of the English Language, Random House, New York, 1973.

\section{ACKNOWLEDGEMENTS}

We would like to thank the Mathematical Sciences Research Institute in Berkeley for its generous support during the time when this research was being carried out.

The third and fourth authors were partially supported by NSF and (by the results of this paper) numerous other government agencies.

\section{REFERENCES}

[Lam 1978] T. Y. Lam, Serre's Conjecture, SpringerVerlag, Berlin, 1978.

[Landsburg 1986] S. Landsburg, "The Jimmy's book", Amer. Math. Monthly 93 (1986), 636-638.

[Robert 1973] P. Robert, Dictionnaire alphabétique et analogique de la langue française ("Le Petit Robert"), Société du nouveau Littré, Paris, 1973.

Jean-François Mestre, Université de Paris 7, 2 place Jussieu, 75005 Paris, France (mestre@mathp7.jussieu.fr)

René Schoof, Dipartimento di Matematica, Università di Trento, I-38050 Povo, Trento, Italy (schoof@volterra.science.unitn.it)

Lawrence Washington, Department of Mathematics, University of Maryland, College Park, MD 20742, USA (lcw@amalie.umd.edu)

Don Zagier, Max-Planck-Institut für Mathematik, Gottfried-Claren-Str. 26, 53225 Bonn, Germany (don@antigone.mpim-bonn.mpg.de)

Received September 18, 1992; accepted in revised form July 16, 1993 